Науковий вісник Івано-Франківської академії Івана Золотоустого "Добрий Пастир». Богослов'я. Філософія. Історія. - 2019. - Вип. 14.

УДК 37:27-47:271.4

\title{
Християнська педагогіка
}

\section{ПРОБЛЕМНІ АСПЕКТИ ХРИСТИЯНСЬКОГО ВИХОВАННЯ В ОЦІНЦІ О. ДМИТРА БЛАЖЕЙОВСЬКОГО}

\section{Леся ВАСЬКІВ}

Навчально-виховний комплекс «Школа-садок «Софія»», вул. Героїв Крут, 27, 79000, Львів, Украӥна

e-mail: vlesja@gmail.com

\section{Андрій ВАСЬКІВ}

Львівський національний університет імені Івана Франка, кафедра теорії та історії культури, вул. Університетська,1,79000, Львів, Україна

e-mail: e-mail: andmaros@ukr.net

Розглянуто проблемні аспекти національно-релігійного виховання українців в оцінці відомого богослова та історика Церкви о. д-ра Дмитра Блажейовського. Проаналізовано виховний потенціал Церкви, досліджено методологію християнського виховання, напрацьвовану педагогічною практикою у церковному середовищі. Здійснено екстраполящію форм і методів релігійного виховання у площину сучасного освітнього простору.В інтерпретачії о. Д.Блажейовського осмислено важливість співпраці сім'ї, Церкви та школи у справі християнського виховання підростаючого покоління

Ключові слова: християнське виховання, духовність, освіта, мораль, християнська етика, Церква,сім'я, учитель.

The problematic aspects of the national-religious education of Ukrainians in the evaluation of the famous theologian and historian of the Church of Fr. Dr. Dmitry Blazheyovsky. The educational potential of the Church is analyzed, the methodology of Christian upbringing, worked out by pedagogical practice in the church environment, is researched. The extrapolation of the forms and methods of religious education into the plane of modern educational space was carried out. In interpretation of. D. Blazheyevsky reflects on the importance of cooperation between family, church and school in the cause of Christian upbringing of the younger generation.

Key words: Christian upbringing, spirituality, education, morality, Christian ethics, church, family, teacher.

Традиція української духовності базується на християнських моральних засадах. Більш ніж тисячолітній досвід українського християнства витворив унікальний у своєму роді синтез інтелектуального потенціалу українства, помноженого на скарби християнської духовності. Роки незалежності України підтвердили винятковий потенціал співпраці Церкви і шкільництва.

Саме завдяки зусиллям християнських Церков, у західному регіоні України 31991 р. у загальноосвітніх середніх школах викладається предмет «Християнська етика». Процес співпраці Церков у царині викладання християнської етики активізувався після доручення Президентом України Міністерству освіти і науки України розробити шкільний курс «етики віри» (2005 р.) Таким чином, в Україні поволі, доволі проблемно, але відбувається процес гуманізації сфери освіти, наповнення іiі змісту традиційними 
Науковий вісник Івано-Франківської академї Івана Золотоустого Добрий Пастир». Богослов'я. Філософія. Історія. - 2019. - Вип. 14.

морально; духовними цінностями, повернення до витокових основ української етнопедагогічної традиції. Однак великою $є$ небезпека формалізації досягнень у справі християнського виховання нашої молоді.

Впровадження християнської етики в школах не повинно перетворити цей предмет на один із предметів. Передовсім, повинні бути присутні розуміння, щире сприйняття та благоговіння. Формальна стандартизація християнської етики може загубити саму ідею виховання, зраціоналізувати предмет, привести до ситуації, в якій «благими намірами вимощена дорога до пекла». Важливо, що Церква звертає увагу передовсім на проблему впровадження в освітній простір християнських моральних цінностей. Певним чином поза увагою ऑiі впливу $\epsilon$ сфера органічного розвитку шкільництва як такого. Умовності українського законодавства, відокремлення Церкви від держави віддаляють сферу впливу релігійних структур від освітянських проблем, а також проблем виховання та навчання підростаючого покоління.

3 огляду на це $\epsilon$ цікавими $\epsilon$ праці греко;католицького священика Дмитра Блажейовського «Поважні недомагання в українському вихованні» (2006) та «Де українська еліта? Еліту треба виховати!» (2008) Деякі їх положення можуть видатися дещо різкими та провокативними, окремі судження - занадто категоричними. Однак цю контроверсійність можна виправдати щирим уболіванням за долю свого народу та його майбутнє. Автор із болем констатує факт „відсталости” українства від цивілізацій, котрі ще 150 років тому мали низький рівень розвитку, зокрема японської та корейської. Причину такого сумного стану справ він вбачає у «бракові виховання... та різнорідного знання».

Головна мета праць, на думку самого автора, полягає у заохоченні до науки всіх, хто хоче дещо знати про виховання. Він акцентує на необхідності заохочувати кожного більше «думати про свою національність та свою релігію, рідну мову». Втрата історичної пам'яті веде до жалюгідного стану «печерних людей кам'яної доби». Д. Блажейовський звертає увагу читача на негативні риси та сторінки історії українців, про які «вони мало думають і не стараються їх усунути». Головними причинами «хворіб українського виховання» $\epsilon$ пасивність, інерція, неорганізованість, брак ініціятиви та співпраці, а також «лінивство, нехіть до вивчення української мови, історії та культури».

Очевидно, варто погодитися 3 автором, що справою виховання українських дітей повинні займатися українці, а не «росіяни, румуни, американці, турки тощо». Додамо також, і це дуже важливо, що виховувати підростаюче покоління української молоді повинні українці, котрі добре знають реалії українського буття, загрози та небезпеки сучасного світу. В цьому контексті цілком справедливою видається заувага о. Блажейовського про те, що «українці повинні розвивати себе самих і власну науку й культуру, власну державу, власну Церкву, власну економію і оборону, та не летіти до чужих 3 думкою, що чужі 3 любови... задармо чогось навчать»[2; с.301]. 
Науковий вісник Івано-Франківської академії Івана Золотоустого "Добрий Пастир». Богослов'я. Філософія. Історія. - 2019. - Вип. 14.

Цілком слушно різко критикує автор систему закордонних студій, передовсім богословських. «Школи і західні університети давали і дають знання, однак у більшості ані не формували, ні не формують людини для самостійного думання, до якоїсь самостійної праці». Аргументом, що підтверджує цю тезу, $\epsilon$ наведений Д. Блажейовським факт мізерної кількости опублікованих докторських праць, який $є$ несумірний із кількістю праць захищених.

Від справи навчання дітей та науки в цілому залежить українське майбутнє. I запорукою цього майбутнього о. Блажейовський називає „розвинутий мозок”, вдосконалення самосвідомости, усвідомлення власної самоцінности та ідентичности. Уможливити оптимізацію виховної концепції українства може, на думку священика, кардинальний перегляд справи підготовки нашого духовенства, інтелігенції та вчителів. Варто погодитися із твердженням про те, що школа та духовенство не можуть дати дітям «доброго національного, морального та релігійного хребта», якщо «самі того хребта не мають» і про «добре виховання своїх дітей... зовсім не дбають». На проблему виховання дітей о. Блажейовський закликає дивитися більш комплексно, не обмежуючись лише присутністю християнського богословського компоненту у шкільних програмах. «Школи та Церкви не вистачає в житті, якщо хтось хоче більше знати і до чогось в житті дійти». [2;c.315].

Автор цікаво аналізує теоретичні аспекти виховного процесу. Виховання та формацію людини ділить на 5 видів. Перший інтелектуальний. Інтелектуальне виховання людині повинні дати «родичі, оточення, школа, Церква і читання». Моральне виховання детермінується тими ж чинниками. I головним у цьому процесі є особистий добрий приклад. Ще одним видом виховної традиції є соціяльне; товариське виховання, до якого входить загальна формація людини та правила доброго тону. Окремо виділяється також релігійне виховання та формування життєвої мети. Важливо звернути увагу на те, що всі перелічені види виховання залежать першочергово від сім'ї та родини. Школа може і повинна доповнювати первинні засади родинного виховання, але вона лише долучається до цього та співдіє 3 ним. Тому важливо опонувати поширеній думці про те, що вся відповідальність за виховання дітей лежить першочергово на школі. Авторам цих рядків доводилося чути навіть твердження про те, що погана поведінка школярів чи якісь їх провини повністю залежать від викладання християнської етики в школі. Приймаючи такі аргументи, ми повертаємося до жахливих традицій „псевдовиховання” радянських часів, коли панувала одна ідеологія, а ті, хто іiі пропагують, були відповідальними за всіх і за все. [2; c.320-327].

Розпачливою сьогодні є ситуація, коли величезна кількість українських родин є неповними, коли батьки змушені заробляти за кордоном, а діти залишені на поталу вулиці та впливу далеко не найкращих зразків масової культури. Тому у співпраці школи та родини, як справедливо зауважує о. Блажейовський, потрібна співдія. В зворотному випадку на нас чекає та сама 
Науковий вісник Івано-Франківської академії Івана Золотоустого "Добрий Пастир». Богослов'я. Філософія. Історія. - 2019. - Вип. 14.

ситуація, що і в українській діаспорі світу, де «молоді у церкві в неділю майже немає», занедбана традиція рідної мови тощо.

Одним із найповажніших недомагань українського виховання цілком справедливо названа «економічна злиденність», відтак брак коштів на книги та й узагалі нехіть до читання. Як аргумент Дмитро Блажейовський наводить цікаву історичну ретроспективу - Квітка-Основ’яненко «500 книжок видрукував і лише 50 продав, а...непродані і даром ніхто не хотів брати». Надзвичайно актуальною сьогодні є справа елітарного виховання, виховання тих, від кого в майбутньому залежатиме майбутнє України.

Автор пропагує здорове прагнення кожного стати елітою, отримати добре виховання та добрі знання, інтенсивно працювати 3 «користю для других та для загального добра усіх». О. Блажейовський виділяє загальні передумови для виховання еліти. На нашу думку, ці зауваги можуть стати надзвичайно корисними у справі формування «здорового суспільства».

Першочерговою умовою елітарного виховання о. Блажейовський називає загальне та національне виховання, яке у родині слід починати ще до народження дитини. Особливо слід наголосити на доброму прикладі батьків, їх намаганні терпляче коректувати поведінку та характер дитини [1; с.73]. окремо наголошується на вагомості шкільного виховання, яке, на думку автора, має бути наповнене духовно-патріотичним змістом та зорієнтоване на формування національно свідомої та всебічно розвинутої і духовно багатої особистості.

Особлива увага у комплексі виховних чинників відводиться релігійному вихованню, яке повинні провадити Церква i духовенство, яке теж повинно бути елітарним, і акцентувати на важливості «християнської любові» та «братньому співжиттю та співпраці» [1;с.94].

Отож, потрібно мати «рішучу і тверду постанову», бажання постійно вчитися і чогось прагнути, розвивати у собі всестороннє ми; слення, мати ініціятиву та уміти ii розвинути і зреалізувати. Цей ,рецепт” надзвичайно простий і складний водночас. Однак, якщо ми хочемо змінити стан справ, необхідно діяти за цією схемою і покласти їі в основу сучасної системи національного виховання. Книжки о. Блажейовського містять ще чимало цікавих та неоднозначних суджень, історичних ретроспектив, які, на нашу думку, заслуговують на існування, а більше того - на ознайомлення. Вважаємо, що згадувані праці варто перечитати всім, хто має дотичність до справи виховання та навчання підростаючого покоління. Пропонована автором самокритичність щодо оцінки власних недоліків може видаватися дещо різкою. Однак, якщо ми хочемо щось змінити, повинні починати з себе. Зцілення може наступити лише у тому випадку, якщо хворобу лікувати. Засіб лікування, запропонований о. Дмитром Блажейовським, $\epsilon$ ефективним i зводиться до усвідомлення нами власних помилок, наполегливої праці, навчання та усвідомлення власної ідентичності. 
Науковий вісник Івано-Франківської академії Івана Золотоустого "Добрий Пастир». Богослов'я. Філософія. Історія. - 2019. - Вип. 14.

\section{СПИСОК ВИКОРИСТАНИХ ДЖЕРЕЛ}

1. Блажейовський Дмитро.Де українська еліта? Еліту треба виховати!. - Львів, 2008. $159 \mathrm{c}$.

2. Блажейовський о. Дмитро. Поважні недомагання в українському вихованні. - Львів, 2006. $-416 \mathrm{c}$.

\section{REFERENCES}

1. Blazheiovskyi Dmytro.De ukrainska elita? Elitu treba vykhovaty!. - Lviv, 2008. - 159 s.

2. Blazheiovskyi o. Dmytro. Povazhni nedomahannia v ukrainskomu vykhovanni. - Lviv, 2006. $-416 \mathrm{~s}$

Дата надходження до редакції: 09.10. 2018 